\title{
HEMODYNAMIC EFFECTS OF 1-HYDRAZINOPHTHALAZINE IN PATIENTS WITH ARTERIAL HYPERTENSION ${ }^{1}$
}

\author{
By GEORGE G. ROWE, ${ }^{2}$ JOHN H. HUSTON, ${ }^{3}$ GEORGE M. MAXWELL, ARCHER P. \\ CROSLEY, JR., AND CHARLES W. CRUMPTON WITH THE TECHNICAL ASSISTANCE \\ oF BERYL WELCH AND AUDREY PETERSON
}

\author{
(From the Cardiovascular Research Laboratory and the Department of Medicine, University \\ of Wisconsin Medical School, and the University Hospitals, Madison, Wis.)
}

(Submitted for publication July 15, 1954 ; accepted September 29, 1954)

\begin{abstract}
Although the literature concerning 1-hydrazinophthalazine (Hydralazine) contains many reports of its effects on arterial blood pressure, its relation to various vasomotor reflexes and autonomic blocking agents (1-4), as well as detailed studies of its pharmacological action in animals (5-7), information concerning hemodynamic effects in subjects having essential arterial hypertension is incomplete. The present report concerns various hemodynamic observations in 17 hypertensive patients to whom Hydralazine was administered intravenously.
\end{abstract}

\section{MATERIAL AND METHODS}

This study was done on 17 postabsorptive subjects chosen from the general medical wards. The clinical diagnosis in each case was essential hypertension, although one patient (No. 15) had, in addition, old chronic pyelonephritis involving the lower half of the left kidney. None of these patients was in cardiac decompensation clinically or as measured by the central venous pressure at the time of study. Special effort was made to secure basal conditions by maintaining as much comfort as possible and by explaining the procedure to the patient prior to the day of catheterization and again prior to each step of the procedure. One member of the team tried to establish rapport with each patient during the study by engaging him or her in light conversation about a non-medical subject, preferably one of the subject's choosing.

Cardiac output was determined in the supine position by means of the Fick principle. This was accomplished by placing a cardiac catheter in the pulmonary artery and an indwelling needle in a peripheral artery, usually the femoral. Expired air was collected for three minutes in a Tissot spirometer and analyzed by the Scholander

1 This investigation was supported in part by grants to the Cardiovascular Research Laboratory of the University of Wisconsin from the Wisconsin Heart Association, Wisconsin Alumni Research Foundation, and $\mathrm{Na}$ tional Heart Institute of the National Institutes of Health, Public Health Service.

2 American Heart Association Research Fellow.

3 Wisconsin Heart Association Research Fellow. apparatus for $\mathrm{O}_{2}$ and $\mathrm{CO}_{2}$ to 0.02 volumes per 100 cc. accuracy. Blood was collected in oiled heparinized syringes during the second minute of the output determination and analyzed for $\mathrm{O}_{2}$ and $\mathrm{CO}_{2}$ content by the Van Slyke-Neill method (8). Duplicate analyses of oxygen content were required to check within 0.2 volumes per $100 \mathrm{cc}$. Direct recordings of blood pressure were made through short flexible plastic tubes connected to Statham strain gauges and through a direct writing Sanborn Poly-Viso. Mean arterial blood pressures were obtained by planimetric integration of the arterial pulse tracing during the first and third minute of the cardiac output determination. Cardiac work and arterial resistances were calculated by the usual formulae $(9,10)$.

After control determinations, Hydralazine in the dosage indicated in Table I was given through the cardiac catheter into the pulmonary artery. The blood pressure was then observed by continuous inspection of the arterial pressure tracing until it had decreased and stabilized at its new level for at least 10 minutes. An average of 43 minutes elapsed following drug administration before the second cardiac output was determined. During this time some of the subjects had cerebral, some coronary, and some renal hemodynamic studies.

\section{RESULTS}

The results are shown in Table I. They are divided into two groups because of the marked yet unpredictable difference in response. Twelve patients, called Group One, experienced mild nasal obstruction, cutaneous facial flushing, and palpitation but no particular discomfort. Five subjects, called Group Two, experienced an adverse reaction characterized by a marked fall in blood pressure, pallor, apprehension, diaphoresis, nausea, and frequently emesis. When this occurred, 100 per cent $\mathrm{O}_{2}$ was given by mask to produce relief of the patient's discomfort and a rise in blood pressure. In these cases the determination of the second cardiac output was delayed until the blood pressure was stable and symptoms were absent. One patient (No. 16) had a blood pressure fall from a mean of 173 to $24 \mathrm{~mm}$. $\mathrm{Hg}$ accompanied by 
TABLE I

Hemodynamic functions before

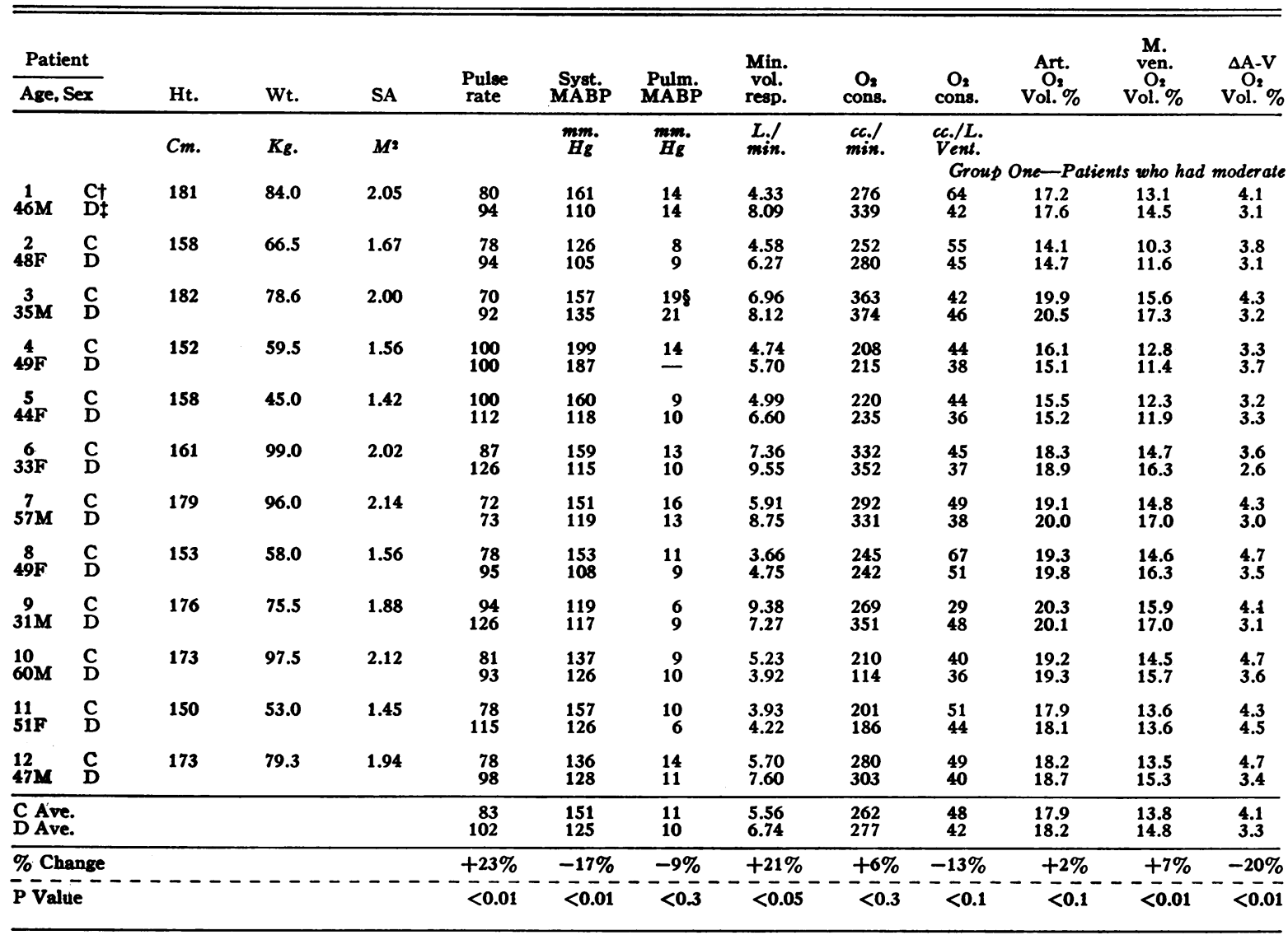

Group Two-Patients who had marked

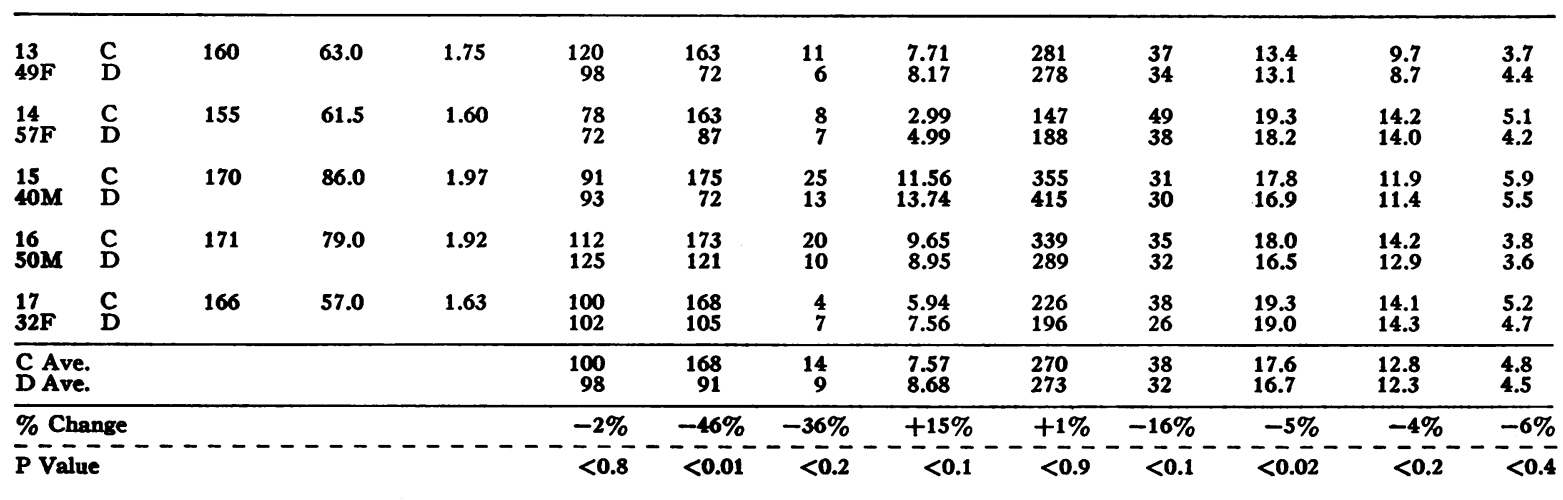

* Syst $\mathbf{M}^{2}-$ Surface area in square meters.

Syst. MABP-Systemic mean arterial blood pressure in $\mathrm{mm}$. $\mathrm{Hg}$.

Min. vol. resp. L./min.Minute volume of air.

$\mathrm{O}_{2}$ cons. cc./min.-Oxysen consumption, $c c$. per minute.

$O_{2}$ cons. $c c$. $/ L$. Vent.- Oxysen consumption, $c c$. per litre ventilation.

Art. $\mathrm{O}_{2}$ Vol. \%-Arterial oxygen content in cc. per $100 \mathrm{cc}$. blood.

M. Ven. $\mathrm{O}_{2}$ Vel. \% - Mixed venous oxyen content in cc. per $100 \mathrm{cc}$. blood.

$\triangle \mathrm{A}-\mathrm{V} \mathrm{O}_{2} \mathrm{Vol}$. \% -Arterial-mixed venous oxygen difference in cc. per $100 \mathrm{cc}$. blood.

Art. $\mathrm{CO}_{2}$ Vol. \%-Arterial $\mathrm{CO}_{2}$ content in $\mathrm{cc}$. per $100 \mathrm{cc}$. of blood

M. V. CO, Vol. \%-Mired venous $\mathrm{CO}$ content in $\mathrm{cc}$. per $100 \mathrm{cc}$. of blood.

$\triangle \mathrm{A}-\mathrm{V}$ CO 2 Vol. \%-Arterial-mixed venous $\mathrm{CO}_{2}$ difference in $c$. per $100 \mathrm{cc}$. blood.

$\mathrm{CO}_{2}$ prod. cc./min.- $\mathrm{CO}_{2}$ expired in cc. per min.

C.I.-Cardiac index in litres per square meter surface area per minute. 
TA BLE I

and after 1-hydrasinophthalasine*

\begin{tabular}{|c|c|c|c|c|c|c|c|c|c|c|c|c|}
\hline $\begin{array}{c}\text { Art. } \\
\text { Co: } \\
\text { vol. \% }\end{array}$ & $\underset{\text { val. \% }}{\mathbf{M} . \mathbf{v} .}$ & $\begin{array}{c}\Delta \mathrm{A}-\mathrm{V} \\
\mathrm{CO} \\
\mathrm{Vol} . \%\end{array}$ & $\begin{array}{c}\mathrm{CO}_{2} \\
\text { prod. }\end{array}$ & C.I. & $\begin{array}{l}\text { Tot. } \\
\text { syest. } \\
\text { resist. }\end{array}$ & $\begin{array}{l}\text { Tot. } \\
\text { pulm. } \\
\text { reaist. }\end{array}$ & $\underset{\text { work }}{\mathbf{L V}}$ & $\begin{array}{c}\mathbf{R V} \\
\text { work }\end{array}$ & $\begin{array}{l}\text { Drug } \\
\text { doee }\end{array}$ & $\begin{array}{l}\text { Time } \\
\text { from } \\
\text { drug } \\
\text { to Co }\end{array}$ & C.V.P. & R.Q. \\
\hline hypotexs: & after hyd & assinophth & $\begin{array}{l}\text { cc./min. } \\
\text { lassine }\end{array}$ & $L . / m^{2}$ & \multicolumn{2}{|c|}{$\begin{array}{c}\text { dymes/cm. } \\
\text { sec. }\end{array}$} & \multicolumn{2}{|c|}{$\begin{array}{l}K_{8 .} \text { meters/ } \\
\text { mm. }\end{array}$} & $m g . / K_{g}$. & $\min$. & $m m . H_{8}$ & \\
\hline $\begin{array}{l}46.9 \\
41.7\end{array}$ & $\begin{array}{l}48.9 \\
43.7\end{array}$ & $\begin{array}{l}2.0 \\
2.0\end{array}$ & $\begin{array}{l}165 \\
231\end{array}$ & $\begin{array}{l}3.3 \\
5.3\end{array}$ & $\begin{array}{r}1,918 \\
805\end{array}$ & $\begin{array}{l}167 \\
102\end{array}$ & $\begin{array}{l}14.7 \\
16.3\end{array}$ & $\begin{array}{l}1.3 \\
2.1\end{array}$ & 0.55 & 56 & $\begin{array}{l}\mathbf{R A}=+3.3 \\
\mathbf{R A}=+0.7\end{array}$ & $\begin{array}{l}0.60 \\
0.68\end{array}$ \\
\hline $\begin{array}{l}50.9 \\
48.0\end{array}$ & $\begin{array}{l}54.0 \\
49.9\end{array}$ & $\begin{array}{l}3.1 \\
1.9\end{array}$ & $\begin{array}{l}158 \\
204\end{array}$ & $\begin{array}{l}4.0 \\
5.4\end{array}$ & $\begin{array}{r}1,518 \\
930\end{array}$ & $\begin{array}{l}97 \\
79\end{array}$ & $\begin{array}{l}11.3 \\
12.8\end{array}$ & $\begin{array}{l}0.7 \\
1.1\end{array}$ & 0.25 & 46 & $\mathrm{ED}=-1.3$ & $\begin{array}{l}0.63 \\
0.73\end{array}$ \\
\hline $\begin{array}{l}49.8 \\
44.5\end{array}$ & $\begin{array}{l}52.2 \\
46.3\end{array}$ & $\begin{array}{l}2.4 \\
1.8\end{array}$ & $\begin{array}{l}243 \\
287\end{array}$ & $\begin{array}{l}4.2 \\
5.9\end{array}$ & $\begin{array}{r}1,485 \\
923\end{array}$ & $=$ & $\begin{array}{l}18.0 \\
21.5\end{array}$ & $\begin{array}{l}2.2 \\
3.4\end{array}$ & 0.34 & 30 & $\begin{array}{l}E D=+1.5 \\
E D=0\end{array}$ & $\begin{array}{l}0.67 \\
0.77\end{array}$ \\
\hline $\begin{array}{l}51.9 \\
45.4\end{array}$ & $\begin{array}{l}54.8 \\
47.3\end{array}$ & $\begin{array}{l}2.9 \\
1.9\end{array}$ & $\begin{array}{l}147 \\
129\end{array}$ & $\begin{array}{l}4.0 \\
3.7\end{array}$ & $\begin{array}{l}2,523 \\
2,571\end{array}$ & 二 & $\begin{array}{l}17.1 \\
14.8\end{array}$ & $\underline{1.2}$ & 0.32 & 45 & $\begin{array}{l}\text { RA }=0 \\
R A=0\end{array}$ & $\begin{array}{l}0.71 \\
0.60\end{array}$ \\
\hline $\begin{array}{l}49.3 \\
43.4\end{array}$ & $\begin{array}{l}51.5 \\
45.8\end{array}$ & $\begin{array}{l}2.2 \\
2.4\end{array}$ & $\begin{array}{l}166 \\
184\end{array}$ & $\begin{array}{l}4.8 \\
5.0\end{array}$ & $\begin{array}{l}1,874 \\
1,341\end{array}$ & $\begin{array}{l}105 \\
108\end{array}$ & $\begin{array}{l}14.8 \\
11.2\end{array}$ & $\begin{array}{l}0.8 \\
0.9\end{array}$ & 0.25 & 55 & $\mathrm{ED}=\overline{0}$ & $\begin{array}{l}0.76 \\
0.78\end{array}$ \\
\hline $\begin{array}{l}45.3 \\
39.3\end{array}$ & $\begin{array}{l}47.5 \\
40.7\end{array}$ & $\begin{array}{l}2.2 \\
1.4\end{array}$ & $\begin{array}{l}236 \\
259\end{array}$ & $\begin{array}{l}4.6 \\
6.7\end{array}$ & $\begin{array}{r}1,379 \\
678\end{array}$ & $\begin{array}{r}108 \\
61\end{array}$ & $\begin{array}{l}19.9 \\
21.2\end{array}$ & $\begin{array}{l}1.6 \\
1.9\end{array}$ & 0.33 & 31 & $\begin{array}{l}\mathrm{RA}=-1.9 \\
\mathrm{RA}=-1.8\end{array}$ & $\begin{array}{l}0.71 \\
0.73\end{array}$ \\
\hline $\begin{array}{l}43.3 \\
39.2\end{array}$ & $\begin{array}{l}47.7 \\
41.3\end{array}$ & $\begin{array}{l}4.4 \\
2.1\end{array}$ & $\begin{array}{l}228 \\
270\end{array}$ & $\begin{array}{l}3.2 \\
5.2\end{array}$ & $\begin{array}{r}1.783 \\
862\end{array}$ & $\begin{array}{r}192 \\
94\end{array}$ & $\begin{array}{l}13.9 \\
17.9\end{array}$ & $\begin{array}{l}1.5 \\
2.0\end{array}$ & 0.25 & 29 & $E D=0$ & $\begin{array}{l}0.78 \\
0.82\end{array}$ \\
\hline $\begin{array}{l}49.5 \\
45.1\end{array}$ & $\begin{array}{l}52.2 \\
48.6\end{array}$ & $\begin{array}{l}2.7 \\
3.5\end{array}$ & $\begin{array}{l}165 \\
183\end{array}$ & $\begin{array}{l}3.3 \\
4.4\end{array}$ & $\begin{array}{l}2,353 \\
1,253\end{array}$ & $\begin{array}{l}164 \\
105\end{array}$ & $\begin{array}{l}10.9 \\
10.2\end{array}$ & $\begin{array}{l}0.8 \\
0.9\end{array}$ & 0.25 & 26 & $E D=+1.4$ & $\begin{array}{l}0.67 \\
0.76\end{array}$ \\
\hline $\begin{array}{l}43.0 \\
39.1\end{array}$ & $\begin{array}{l}45.7 \\
40.7\end{array}$ & $\begin{array}{l}2.7 \\
1.6\end{array}$ & $\begin{array}{l}313 \\
221\end{array}$ & $\begin{array}{l}3.3 \\
6.0\end{array}$ & 1,554 & $\begin{array}{l}83 \\
60\end{array}$ & $\begin{array}{r}9.9 \\
17.9\end{array}$ & $\begin{array}{l}0.5 \\
1.3\end{array}$ & 0.25 & 53 & $\mathrm{RA}=-2.2$ & $\begin{array}{l}1.16 \\
0.63\end{array}$ \\
\hline $\begin{array}{l}39.8 \\
38.2\end{array}$ & $\begin{array}{l}43.9 \\
40.3\end{array}$ & $\begin{array}{l}4.1 \\
2.1\end{array}$ & $\begin{array}{l}164 \\
103\end{array}$ & $\begin{array}{l}2.1 \\
1.9\end{array}$ & $\begin{array}{l}2,454 \\
2,562\end{array}$ & $\begin{array}{l}165 \\
197\end{array}$ & $\begin{array}{l}8.3 \\
6.7\end{array}$ & $\begin{array}{l}0.6 \\
0.5\end{array}$ & 0.20 & 32 & $R A=0$ & $\begin{array}{l}0.78 \\
0.73\end{array}$ \\
\hline $\begin{array}{l}50.0 \\
45.9\end{array}$ & $\begin{array}{l}53.5 \\
49.1\end{array}$ & $\begin{array}{l}3.5 \\
3.2\end{array}$ & $\begin{array}{l}145 \\
129\end{array}$ & $\begin{array}{l}3.2 \\
2.9\end{array}$ & $\begin{array}{l}2,685 \\
2,427\end{array}$ & $\begin{array}{l}160 \\
123\end{array}$ & $\begin{array}{r}10.0 \\
7.1\end{array}$ & $\begin{array}{l}0.6 \\
0.4\end{array}$ & 0.20 & 30 & $\begin{array}{l}\text { ED }=+0.9 \\
\text { ED }=+0.9\end{array}$ & $\begin{array}{l}0.72 \\
0.70\end{array}$ \\
\hline $\begin{array}{l}45.3 \\
39.7\end{array}$ & $\begin{array}{l}48.1 \\
41.5\end{array}$ & $\begin{array}{l}2.8 \\
1.8\end{array}$ & $\begin{array}{l}200 \\
207\end{array}$ & $\begin{array}{l}3.1 \\
4.6\end{array}$ & $\begin{array}{l}1,826 \\
1,147\end{array}$ & $\begin{array}{r}189 \\
96\end{array}$ & $\begin{array}{l}11.0 \\
15.5\end{array}$ & $\begin{array}{l}1.1 \\
1.3\end{array}$ & 0.25 & 30 & $\begin{array}{l}\mathrm{ED}=+3.9 \\
\mathrm{ED}=+3.0\end{array}$ & $\begin{array}{l}0.71 \\
0.68\end{array}$ \\
\hline $\begin{array}{l}47.1 \\
42.5\end{array}$ & $\begin{array}{l}50.0 \\
44.6\end{array}$ & $\begin{array}{l}2.9 \\
2.1\end{array}$ & $\begin{array}{l}194 \\
201\end{array}$ & $\begin{array}{l}3.6 \\
4.8\end{array}$ & $\begin{array}{l}1,963 \\
1,360\end{array}$ & $\begin{array}{l}143 \\
103\end{array}$ & $\begin{array}{l}13.3 \\
14.4\end{array}$ & $\begin{array}{l}1.1 \\
1.4\end{array}$ & 0.29 & 39 & & $\begin{array}{l}0.74 \\
0.72\end{array}$ \\
\hline $\begin{array}{l}-10 \% \\
=-\overline{0} \\
<0.01\end{array}$ & $\begin{array}{l}-10 \% \\
=-\overline{<0}\end{array}$ & $\begin{array}{l}-24 \% \\
<0.01\end{array}$ & $\begin{array}{r}+4 \% \\
-\quad<0.7\end{array}$ & $\begin{array}{l}+33 \% \\
-<0.01\end{array}$ & $\begin{array}{l}-319 \\
<0.0\end{array}$ & $\begin{array}{l}-28 \% \\
<0.02\end{array}$ & $\begin{array}{l}+8 \% \\
<0\end{array}$ & $\begin{array}{l}+27 \% \\
+<-\frac{5}{<05}\end{array}$ & & & & $-\frac{-3 \%}{<0.7}$ \\
\hline
\end{tabular}

hypotension after 1-hydrasinophthalasine

\begin{tabular}{|c|c|c|c|c|c|c|c|c|c|c|c|c|}
\hline $\begin{array}{l}46.4 \\
42.9\end{array}$ & $\begin{array}{l}50.0 \\
45.1\end{array}$ & $\begin{array}{l}3.6 \\
2.2\end{array}$ & $\begin{array}{l}211 \\
195\end{array}$ & $\begin{array}{l}4.4 \\
3.6\end{array}$ & $\begin{array}{r}1,713 \\
805\end{array}$ & $\begin{array}{r}116 \\
81\end{array}$ & $\begin{array}{r}16.9 \\
5.5\end{array}$ & $\begin{array}{l}1.1 \\
0.6\end{array}$ & 0.35 & 51 & $E D=-1$ & $\begin{array}{l}0.75 \\
0.70\end{array}$ \\
\hline $\begin{array}{l}46.4 \\
42.2\end{array}$ & $\begin{array}{l}49.5 \\
44.6\end{array}$ & $\begin{array}{l}3.1 \\
2.4\end{array}$ & $\begin{array}{r}88 \\
125\end{array}$ & $\begin{array}{l}1.8 \\
2.8\end{array}$ & $\begin{array}{l}4,551 \\
1,553\end{array}$ & $\begin{array}{l}246 \\
129\end{array}$ & $\begin{array}{l}6.4 \\
5.3\end{array}$ & $\begin{array}{l}0.4 \\
0.4\end{array}$ & 0.25 & 45 & $\begin{array}{l}\mathrm{ED}=-1 \\
\mathrm{ED}=-1.5\end{array}$ & $\begin{array}{l}0.60 \\
0.67\end{array}$ \\
\hline $\begin{array}{l}43.5 \\
38.5\end{array}$ & $\begin{array}{l}49.1 \\
43.3\end{array}$ & $\begin{array}{l}5.6 \\
4.8\end{array}$ & $\begin{array}{l}340 \\
326\end{array}$ & $\begin{array}{l}3.1 \\
3.8\end{array}$ & $\begin{array}{r}2.326 \\
762\end{array}$ & $\begin{array}{l}332 \\
132\end{array}$ & $\begin{array}{r}14.3 \\
7.4\end{array}$ & $\begin{array}{l}2.0 \\
1.3\end{array}$ & 0.30 & 42 & $\mathrm{ED}=0$ & $\begin{array}{l}0.96 \\
0.78\end{array}$ \\
\hline $\begin{array}{l}45.1 \\
45.1\end{array}$ & $\begin{array}{l}47.5 \\
47.7\end{array}$ & $\begin{array}{l}2.4 \\
2.6\end{array}$ & $\begin{array}{l}262 \\
242\end{array}$ & $\begin{array}{l}4.6 \\
4.2\end{array}$ & $\begin{array}{l}1,551 \\
1,243\end{array}$ & $\begin{array}{r}179 \\
98\end{array}$ & $\begin{array}{l}21.0 \\
13.7\end{array}$ & $\begin{array}{l}2.4 \\
1.1\end{array}$ & 0.25 & 102 & $\begin{array}{l}\mathrm{ED}=+2.4 \\
\mathrm{RA}=-0.3\end{array}$ & $\begin{array}{l}0.77 \\
0.84\end{array}$ \\
\hline $\begin{array}{l}44.7 \\
39.7\end{array}$ & $\begin{array}{l}48.4 \\
42.8\end{array}$ & $\begin{array}{l}3.7 \\
3.1\end{array}$ & $\begin{array}{l}166 \\
179\end{array}$ & $\begin{array}{l}2.7 \\
2.6\end{array}$ & $\begin{array}{l}3,077 \\
2,021\end{array}$ & $\begin{array}{r}81 \\
131\end{array}$ & $\begin{array}{l}9.9 \\
6.0\end{array}$ & $\begin{array}{l}0.3 \\
0.4\end{array}$ & 0.25 & 32 & $\begin{array}{l}\mathrm{ED}=-2 \\
\mathrm{ED}=-2\end{array}$ & $\begin{array}{l}0.73 \\
0.92 \\
\end{array}$ \\
\hline $\begin{array}{l}45.2 \\
41.7\end{array}$ & $\begin{array}{l}48.9 \\
44.7\end{array}$ & $\begin{array}{l}3.7 \\
3.0\end{array}$ & $\begin{array}{l}213 \\
213\end{array}$ & $\begin{array}{l}3.3 \\
3.4\end{array}$ & $\begin{array}{l}2,644 \\
1,277\end{array}$ & $\begin{array}{l}191 \\
114\end{array}$ & $\begin{array}{r}13.7 \\
7.6\end{array}$ & $\begin{array}{l}1.2 \\
0.8\end{array}$ & 0.28 & 54 & & $\begin{array}{l}0.76 \\
0.78\end{array}$ \\
\hline $\begin{array}{l}-8 \% \\
--8.02 \\
<0.02\end{array}$ & $\begin{array}{l}-9 \% \\
-<0.02\end{array}$ & $\begin{array}{l}-19 \% \\
<0.05\end{array}$ & 0 & $\begin{array}{l}+3 \% \\
<0.9\end{array}$ & $\begin{array}{l}-52 \% \\
-<0.05\end{array}$ & $\begin{array}{r}-40 \% \\
-<0.2\end{array}$ & $<0.02$ & $=\frac{-33 \%}{<0.2}$ & & & & $\begin{array}{l}+3 \% \\
- \pm\end{array}$ \\
\hline
\end{tabular}

Tot. syst. resist.-Total systemic arterial resistance in dynes per $\mathrm{cm} .-5 / \mathrm{sec}$.

Tot. pulm. resist.-Total pulmonary arterial resistance in dynes per $\mathrm{cm} .^{-\mathrm{s}} / \mathrm{sec}$.

LV work-Left ventricular work in $\mathbf{K}$. meters per minute.

Time from drug to CO-Time in minutes between the administration of the drug and the determination of the second cardiac output. C.V.P. - Central venous pressure measured either as right ventricular end diastolic pressure (ED) or right atrial mean
(ED) R.Q.- Respiratory quotient for total body.

t Control.

f After Hydralazine.

Right ventricular systolic mean. 
nodal bradycardia. $\mathrm{He}$ was given $\mathrm{O}_{2}$ by mask, then methoxamine $2 \mathrm{mg}$. intravenously, followed by $12 \mathrm{mg}$. intramuscularly, to maintain his pressure high enough for the second output. The data derived from this study would have been omitted from the report except that his response is similar to the rest of those in Group Two. The average dose of Hydralazine was the same in both groups.

The cardiac rate in Group One increased from a mean in the control period of 83 beats per minute to a mean of 102 beats per minute $(p<0.01)$ after the intravenous administration of Hydralazine. In Group Two, who had marked hypotension, no increase in pulse rate occurred, and in two cases (No. 15 and No. 16) there was nodal rhythm with bradycardia during the period of greatest hypotension.

Systemic arterial blood pressure consistently fell. The average fall of the mean pressure in Group One was $26 \mathrm{~mm}$. $\mathrm{Hg}(\mathrm{p}<0.01)$, and in Group Two $77 \mathrm{~mm}$. Hg ( $<<0.01)$. In Group Two the average maximum fall in blood pressure was $108 \mathrm{~mm}$. $\mathrm{Hg}$ and was usually transient. Effort was made to prevent such falls by decreasing the Hydralazine dose gradually during the series but they occurred unpredictably. The decrease in the pulmonary arterial pressure was not statistically significant in either group. Calculation of cardiac output indicated that there was an increase of 33 per cent $(p<0.01)$ in Group One and no change in Group Two. Stroke volume rose slightly but not significantly in both groups. Peripheral arterial resistance was reduced by 31 per cent $(p<0.01)$ in Group One and 52 per cent in Group Two ( $p<0.05)$, whereas total pulmonary resistance fell by 28 per cent $(p<0.02)$ and 40 per cent $(p<0.2)$, respectively, in the two groups. With the concomitant fall in peripheral arterial blood pressure and the change in cardiac output, cardiac work against pressure fluctuated unpredictably. The left ventricular work fell in Group Two $(-45$ per cent, $p<0.02)$ and right ventricular work rose in Group One $(p<$ 0.05).

In Group One $\mathrm{O}_{2}$ consumption and arterial $\mathrm{O}_{2}$ level were not significantly changed by Hydralazine. The increased cardiac output produced a decrease in arteriovenous $\mathrm{O}_{2}$ difference $(\mathrm{p}<$
0.01 ) because of the increase in the mean mixed venous $\mathrm{O}_{2}$ content of 1.0 volume per $100 \mathrm{cc}$. By contrast, in Group Two there was a fall in arterial $\mathrm{O}_{2}$ content $(\mathrm{p}<0.02)$. Here the variability of mixed venous $\mathrm{O}_{2}$ was such that no statistically significant change occurred in the arteriovenous $\mathrm{O}_{2}$ difference. Oxygen consumption remained the same.

In 10 patients of Group One the minute volume of respiration increased after the administration of Hydralazine, the average increase for the entire group being 21 per cent $(p<0.05)$. As would be expected in these circumstances, the arterial $\mathrm{CO}_{2}$, mixed venous $\mathrm{CO}_{2}$ and arterio-mixed venous $\mathrm{CO}_{2}$ difference all decreased $(\mathrm{p}<0.01)$. In Group Two the arterial and venous blood $\mathrm{CO}_{2}$ content changes were similar but less significant, probably because of the smaller number of patients. Constant $\mathrm{CO}_{2}$ production and unchanged respiratory quotients of both groups attested to the attainment of a reasonably steady state by the time of the second hemodynamic determinations.

\section{DISCUSSION}

A previous report of cardiac output after administration of Hydralazine was made by Wilkinson, Backman, and Hecht (11) in a total of six patients. They found a markedly greater increase in the cardiac output in four normotensive patients (average +112 per cent) than in two hypertensive patients (average +19 per cent). Further data are reported by Assali, Kaplan, Oighenstein, and Suyemoto (12) who by the ballistocardiographic method demonstrated an increase in cardiac output and a decrease in peripheral resistance after Hydralazine administration to pregnant normotensive, toxemic and hypertensive subjects. A similar pattern was found by the Fick principle in their three patients with toxemia. Moyer (13) by the pulse contour method, and Freis, Rose, Finnerty, and Partenope (14) by the Fick principle demonstrated an increase in cardiac output. Our observations in general confirm and extend these earlier reports.

The data from Group One suggest that the primary change after administration of Hydralazine to these patients with hypertension is a decrease in the vascular resistance both in the systemic cir- 
culation ( -31 per cent) and in the lung ( -28 per cent). Accompanying this decrease in vascular resistance there is a fall in systemic arterial pressure $(-17$ per cent) and a rise in cardiac output $(+33$ per cent). In spite of the increase in cardiac output, calculated left ventricular pressure work is not increased and the $\mathrm{O}_{2}$ consumption remains essentially the same. It seems clear that the vasodilatation produced by this drug is quite general since it is found in cerebral $(15,16)$, hepatic $(7,14)$, renal $(11,17)$, and coronary vascular beds (18) as well as in the systemic and pulmonary vascular beds as a whole as shown in this study. However, the degree of vasodilatation is not the same in all areas $(11,18)$. Skin temperature was not found to increase generally by Wilkinson, Backman, and Hecht but did occur locally after direct intra-arterial administration (11). It was shown to rise in local areas after intravenous administration in pregnant patients by Assali, Kaplan, Oighenstein, and Suyemoto (12).

The changes produced in Group Two were complicated by the precipitation of marked hypotension and the resulting adjustments which occur secondary to such a hemodynamic condition. It seems probable that this marked hypotensive effect was due to failure of venous return because of peripheral and splanchnic pooling of blood. This cannot be stated with certainty, since the central venous pressure was measured at the beginning and end of the procedure, not during the most hypotensive phase. The slight fall in arterial $\mathrm{O}_{2}$ content appears related to the marked hypotensive phase.

A mild degree of hyperventilation occurred in both groups as shown by the increase in minute volume of respiration, and further manifested by the fall in arterial and venous $\mathrm{CO}_{2}$ contents. $\mathrm{Al}$ though $\mathrm{pH}$ determinations were not done in this study, arterial $\mathrm{pH}$ as determined by Hafkenschiel and his associates (15) showed a slight rise after administration of Hydralazine. The reason for this hyperventilation is not known, but the fact that it was less in the Group Two patients, who were most apprehensive and uncomfortable, suggests that it was not psychogenic.

During the study and in retrospect since its completion an attempt has been made to determine what factor or factors accounted for the different response of Group One and Group Two. Statistical testing indicates that Group Two patients had, on the average, higher mean arterial blood pressure $(p<0.02)$, lower stroke index $(p<$ $0.05)$, and lower $\mathrm{O}_{2}$ consumption per liter ventilation $(p<0.05)$ than Group One patients. None of the other factors which we measured could be shown statistically to be related to the difference in response. It is interesting to speculate that the response to 1-hydrazinophthalazine may be related to cardiac reserve. The increase in cardiac output of normal patients (Wilkinson, Backman, and Hecht) was 112 per cent, our Group One hypertensive subjects had only a 33 per cent increase and the Group Two hypertensive subjects, with an even higher arterial blood pressure, showed no significant change. Other patients in Group One who did not experience adverse symptoms but who had severe hypertension, e.g., No. 4 , or a very low initial cardiac output, as No. 10 , also had no increase in cardiac output after the drug was given. This suggests that there is a continuous spectrum of response from the patient who becomes flushed and warm, develops tachycardia, and increases his cardiac output and left ventricular work to the patient who develops marked hypotension, pallor, sweating, apprehension, bradycardia with nodal rhythm, and whose cardiac output and cardiac work fall.

\section{CONCLUSIONS}

1. Administration of 1-hydrazinophthalazine intravenously to 17 subjects with arterial hypertension produced a decrease in peripheral and pulmonary vascular resistance with a decrease in systemic arterial blood pressure accompanied generally by increased cardiac output. However, when severe hypotension occurred, cardiac output remained the same or fell.

2. Left ventricular work fell when marked hypotension occurred, but otherwise was unchanged.

3. Hyperventilation occurred after Hydralazine administration in 14 of 17 patients with a fall in arterial and mixed venous $\mathrm{CO}_{2}$ and a decrease in arteriovenous $\mathrm{CO}_{2}$ difference.

4. No significant change occurred in $\mathrm{O}_{2}$ consumption, total $\mathrm{CO}_{2}$ production, or respiratory quotient. 


\section{REFERENCES}

1. Grimson, K. S., Chittum, J. R., and Metcalf, B. H., Action of 1-hydrazinophthalazine (C-5968) on vasomotor reflexes and hypertension in dogs and man. Federation Proc., 1950, 9, 279.

2. Britton, J. B., Taylor, J. P., and Ahlquist, R. P., Cardiovascular actions of 2, 3-benzodiazine-4-hydrazine (C-5968). Federation Proc., 1951, 10, 282.

3. Freis, E. D., MacKay, J. C., and Oliver, W. F., The effect of "sympatholytic" drugs on the cardiovascular responses to epinephrine and norepinephrine in man. Circulation, 1951, 3, 254.

4. Walker, H. A., Wilson, S., Atkins, E. C., Garrett, H. E., and Richardson, A. P., The effect of 1-hydrazinophthalazine (C-5968) and related compounds on the cardiovascular system of dogs. J. Pharmacol. \& Exper. Therap., 1951, 101, 368.

5. Craver, B. N., Barrett, W., Cameron, A., and Yonkman, F. F., The activities of 1-hydrazinophthalazine (Ba-5968), a hypotensive agent. J. Am. Pharm. A., 1951, 40, 559.

6. Moyer, J. H., Handley, C. A., and Huggins, R. A., Some pharmacodynamic effects of 1-hydrazinophthalazine (C-5968) with particular reference to renal function and cardiovascular response. $\mathrm{J}$. Pharmacol. \& Exper. Therap., 1951, 103, 368.

7. Marks, P. A., and Reynell, P. C., The effect of 1-hydrazinophthalazine on the hepatic circulation in dogs. (Abst.) J. Clin. Invest., 1953, 32, 586.

8. Van Slyke, D. D., and Neill, J. M., The determination of gases in blood and other solutions by vacuum extraction and manometric measurement. I. J. Biol. Chem., 1924, 61, 523.

9. Lombardo, T. A., Rose, L., Taeschler, M., Tully, S., and Bing, R. J., The effect of exercise on coronary blood flow, myocardial oxygen consumption and cardiac efficiency in man. Circulation, 1953, 7, 71.

10. Dexter, L., Dow, J. W., Haynes, F. W., Whittenberger, J. L., Ferris, B. G., Goodale, W. T., and Hellems, H. K., Studies of the pulmonary circulation in man at rest. Normal variations and the interrelations between increased pulmonary blood flow, elevated pulmonary arterial pressure, and high pulmonary "capillary" pressures. J. Clin. Invest., 1950, 29, 602.

11. Wilkinson, E. L., Backman, H., and Hecht, H. H., Cardiovascular and renal adjustments to a hypotensive agent, (1-hydrazinophthalazine: Ciba BA5968: Apresoline). J. Clin. Invest., 1952, 31, 872.

12. Assali, N. S., Kaplan, S., Oighenstein, S., and Suyemoto, R., Hemodynamic effects of 1-hydrazinophthalazine (Apresoline) in human pregnancy: Results of intravenous administration. J. Clin. Invest., 1953, 32, 922.

13. Moyer, J. H., Hydralazine (Apresoline) hydrochloride, pharmacological observations and clinical results in the therapy of hypertension. Arch. Int. Med., 1953, 91, 419.

14. Freis, E. D., Rose, J. C., Finnerty, F. A., Jr., and Partenope, E. A., A comparative study of the hemodynamic alterations produced by hexamethonium and 1-hydrazinophthalazine (Apresoline) in hypertensive patients. J. Clin. Invest., 1953, 32, 569.

15. Hafkenschiel, J. H., Friedland, C. K., Yobbagy, J., Brandt, H., Merrill, J., and Lincoln, N. K., The effect of 1-hydrazinophthalazine on cerebral blood flow, vascular resistance, oxygen uptake and jugular oxygen tension in hypertensive subjects. J. Clin. Invest., 1953, 32, 655.

16. Crumpton, C. W., Rowe, G. G., Crosley, A. P., Jr., Maxwell, G. M., and Huston, J. H., Cardiovascular, cerebral, and renal hemodynamic and metabolic adjustments to 1-hydrazinophthalazine in essential hypertension. J. Lab. \& Clin. Med., 1953, 42, 797.

17. Crosley, A. P., Jr., Rowe, G. G., and Crumpton, C. $\mathrm{W}$., The hemodynamic and metabolic response of the human hypertensive kidney to a standard dose of 1-hydrazinophthalazine (Hydralazine). J. Lab. \& Clin. Med. In press, July, 1954.

18. Rowe, G. G., Huston, J. H., Maxwell, G. M., Tuchman, H., and Crumpton, C. W., Effect of 1-hydrazinophthalazine on coronary blood flow and cardiac metabolism. Unpublished observations. 